\title{
Research on the Enterprise Annuity System under the Background of \\ Aging in China
}

\author{
Ting Liu \\ Xi 'an FanYi University Economic Management College, Shaanxi, Xi'an, 710000
}

\section{Keywords: Chinese Aging; Enterprise; Annuity System}

\begin{abstract}
At present, all countries are promoting the comprehensive development of the social old-age security system, and in China, although the enterprise annuity system is a very important part of the social old-age security system, but the enterprise pension system has not played it Ideal effect. In China, after a few years of demographic dividend, we began to face the aging problem of aging. The problem of aging is not only manifested in the shortage of new generation of labor, but we need to focus on the issue of old-age security. Therefore, this article will be based on the aging of Chinese population as the background, to start the enterprise annuity system research, hoping to analyze and improve the enterprise annuity system approach, making the system can really promote the cohesion of enterprises and ease the national pension pressure. At present, Chinese basic old-age insurance personal account "empty account" problem has been exposed, so the enterprise pension system needs to be improved and strengthened in order to make the basic old-age insurance "empty account" problem is effectively alleviated, reduce population aging Social and economic negative effects.
\end{abstract}

\section{Introduction}

Chinese recent decades, from the "baby boom" to "family planning", the continuous development of the economy at the same time the medical level is also rising, the aging population accounts for the proportion of the population is getting higher and higher, the country's pension burden unprecedented, but the Chinese economy is still in the development stage, the basic old-age insurance in the "empty account" problem exposed a lot, it was called the second pillar of the pension system, the enterprise pension system has not played the target set when the target effect. As a kind of enterprise annuity system which is linked with the occupation of each employee and has a relatively high protection effect in theory, it should be able to provide a certain standard of living for retirees in good planning and operation, reduce the burden of national pension, the most efficient allocation of social resources. Enterprise annuity should be the benefit of the staff in each enterprise, and it is actually the most common and common incentive mechanism in many developed countries. At present, the enterprise annuity system has a certain effect of implementation, but in the context of Chinese aging population, there are some valuable content we need to dig.

\section{Chinese Population Aging and Enterprise Annuity System}

Summary of Population Aging in China. Since the beginning of the new century, the problem of population aging has become one of the major problems facing China. According to the United Nations report published in 1956, in a country or a region, the number of people older than or equal 
to 65 years of age accounted for more than $7 \%$ of the total number of people, the country or region into the old age The stage of the. Chinese population of the elderly population is very large base, in September 2014 and Chinese 60-year-old population has more than 200 million.

Analysis on the Development Trend of Population Aging in China. In 1982, China was only an adult country, with an elderly population accounting for $5 \%$ of the total population. And just after 17 years, Chinese demographic structure changed from adult to old age. In the Western countries, the Western aging countries will generally be a few decades or even a hundred years to change from adult to adult type. For example, France took 115 years to change this time, the United States is spent sixty years time and Chinese growth rate is very rare. Taking into account the impact of family planning, Chinese population aging in recent years may be difficult to get relief and the proportion of the elderly population will be higher and higher.

History and Current Situation of Chinese Enterprise Annuity. The enterprise annuity system refers to the pension system established spontaneously according to its own operation, financial situation and development goal by the state to promote and guide the state pension system and public pension under the guidance and implementation of the state. The purpose of the establishment of an enterprise annuity system is to provide a certain amount of pension to the retired employees of the enterprise. From the beginning of the 1990s, Chinese enterprise annuity system from the enterprise to supplement the endowment insurance stage began to the current rapid development stage as a whole showing a small scale and coverage is relatively low, the enterprise annuity replacement rate is too low characteristics.

The Significance of Studying the Enterprise Annuity System under the Background of the Aggravation of Population Aging in China. At the present stage of Chinese aging population structure, strengthening and improving the enterprise annuity system can help the whole society to reduce the negative impact of the aging population structure to a certain extent. On the enterprise itself, can help to enhance the cohesion of enterprises, and further enhance the competitiveness of enterprises. The development of the enterprise annuity system can make the existing employees more involved in the distribution of the benefits of enterprises, making the benefits of enterprises and employees more closely linked to the interests of the increase in corporate income on the basis of increased corporate employees in retirement after the pension treatment, reduce the burden of employees of the family pension. Second, not just the enterprise annuity system is the basic system for the welfare of employees, enterprise annuity fund or financial market has a long-term and part of the stability of financial instruments. Most of Chinese pension funds are part of the financial market into the long term, this part of the funds will become an important part of the social capital structure to promote the prosperity and development of capital markets.

\section{Research on the Enterprise Annuity System under the Background of Aging in China}

As the aging population in China is increasing day by day, the enterprise pension system is one of the important pillars in the old-age security system, which can serve to improve the old-age security system and alleviate the pension pressure for the society. The implementation of enterprise annuity system, to share part of the national pension responsibility, the state for the people to provide basic and fair minimum living security level, and enterprises are able to retire employees to bring some additional benefits, bear part of social responsibility. This can not only through the enterprise annuity system to promote the harmonious development of society as a whole, but also to promote employees in the work of a clear sense of responsibility, work hard, responsible for their own old age. From the perspective of Chinese population aging, this paper has done the following aspects of the enterprise annuity system thinking: 
It Should Improve the Enterprise Annuity System from the Perspective of Individual Accounts. In recent years, Chinese basic old-age insurance with the aging of the population trend, the payment of pressure even more serious, personal accounts of the "empty account" problem has repeatedly been exposed. From the employee's personal account point of view, the initial purpose of the enterprise annuity system is to encourage employees to be loyal to the enterprise, reduce the mobility of personnel. But now in this fast-growing society, the basis of social progress is the flow of talent, enterprises should have more room for self-choice, from the enterprise point of view based on individual employees account more choice, you can set a unilateral set of employees to receive Annuity personal account contribution to the full amount of power conditions, so many companies can improve the attractiveness of the labor force and their own competitiveness.

It Should Improve the Enterprise Annuity System from the Perspective of Enterprise. In developed countries, the annuity gradually evolved into an independent accounting asset, and the proportion of pension funds that employees can receive in their pension plans is expanding. In recent years, with the enterprise pension system to gradually mature, enterprise annuity scale is also expanding, annuity assets in the rapid development stage. In order to further promote the development and maturity of related systems, small and medium enterprises and private enterprises are best able to have the power to take the initiative to annihilate, because in these enterprises, cash flow and capital face the impact of production is very large, tight capital chain easily affects the company's development prospects. Therefore, for the development of the company and the annuity of enterprise annuity, if the enterprise within a certain range from the annuity account in a certain proportion of funds for the enterprise's own development, for the expansion and development of the enterprise to assist the capital of the enterprise Value added is a guarantee for employees to receive more annuities in future retirement life.

Consider Merging Individual Accounts to Improve Management Efficiency. In the accounts related to the old age, the staff will have the basic old-age insurance personal account and the enterprise annuity personal account of these two accounts. The amount of money in the employee's personal account is accumulated over a long period of time and cannot be received in advance before retirement, but the property of the asset is owned by the employee. If the employee's enterprise annuity personal accounts and basic pension insurance personal accounts combined to improve the relevant staff and enterprise pension system to implement the management efficiency and reduce the individual account of the "empty account" probability. Through the merger of these two accounts, it is possible to effectively adjust the relative proportion of the basic old-age insurance and the enterprise annuity, so that the enterprise annuity can be constrained by the shortage of space and the development of the basic old-age insurance.

Promote and Support the Financial Market Innovation and Enrich the Annuity Market Content. With the development of enterprise annuity, the scale of enterprise annuity fund is increasing, and the huge fund scale has injected new vitality into Chinese financial market, and opens the window for the innovation of capital market. According to the needs of the enterprise annuity investment channel, the financial market needs to promote the optimal allocation of resources to make the financial resources to gradually increase the value of efficiency. This will be able to complete the supply side of the reform requirements at the supply level to expand the quality of resources, but also to increase the internal needs and improve the vitality of the whole society and economy. Enterprise annuity management of nearly 700 billion of the size of the fund, in the huge size of the fund, any investment behavior can give financial markets to bring new ideas to promote the development of financial innovation, making innovation to ease the current population of China An effective way of aging problems. 
Promote the Construction and Improvement of Annuity Market Supervision System. At present, the implementation of the enterprise annuity system is not obvious enough, in part because the construction of the enterprise annuity supervision system is not perfect. For example, Chinese enterprise annuity fund in the investment process involves a number of institutions and links, regulatory object is very complicated. At present, the supervisory body of Chinese enterprise annuity is the institution of the Ministry of Personnel, which obviously cannot effectively supervise the enterprise annuity fund which has been highly marketed. In order to be able to effectively enhance the ability to pay for pensions and to reduce the "empty account" of individual accounts as much as possible, the investment and operation of enterprise annuities need not only require official regulatory authorities to monitor, But also from the social supervision of the power to carry out specialized supervision.

\section{Conclusion}

Chinese population dividends and then gradually disappear, the problem of population aging has gradually become one of the serious problems affecting social development. In the pension system occupies a very important position of the enterprise annuity system, since the nineties of last century in China since the implementation of a certain effect, but still did not achieve the most ideal in theory the effect. Taking into account the growing problem of population aging, this paper from five angles on the Chinese enterprise annuity system was studied. From the perspective of the enterprise annuity account, the individual account should have a higher degree of flexibility, the performance of the enterprise for employees to get annuity conditions and some enterprises for the control of the annuity of the need for a certain degree of freedom. Second, individual pension accounts can be considered merged to improve management efficiency. Finally, by strengthening the innovation in the financial market and improving the supervision system of the annuity market, the enterprise efficiency can be effectively improved. These analyzes are aimed at the actual benefits of the business and the ability of employees to get as many pensions as possible after retirement to achieve the goal of reducing the negative impact of population aging.

\section{Acknowledgements}

Fund Project: Scientific research project in Shaanxi province department of education in 2014:The adaptability of enterprise annuity in our country development research,(14JK2034).

\section{References}

[1] (School of Economics and Management, Shanghai Jiaotong University, Shanghai 200092, China); Research on the Enterprise Annuity System under the Background of Aging in China [J]. Finance and Economics, 2014, (10): 77-81.

[2] Liu Hongwei. Agglomeration intensified in the context of China's enterprise annuity system research [D]. Guangxi University, 2015

[3] Wang Xiaolong, Dong Dengxin. China's aging under the background of the enterprise annuity thinking [J]. Entrepreneurs World, 2007, (04): 155-156.

[4] Tang Jincheng, Liu Hongwei, Lu Yijiang.On the basis of the implementation of enterprise annuity system under the background of aging [J]. Tianjin Social Insurance, 2015, (02): 17-18. 
[5] Liao Dan. China's enterprise annuity market development of the status quo and problems[D]. Southwest University of Finance and Economics, 2014 